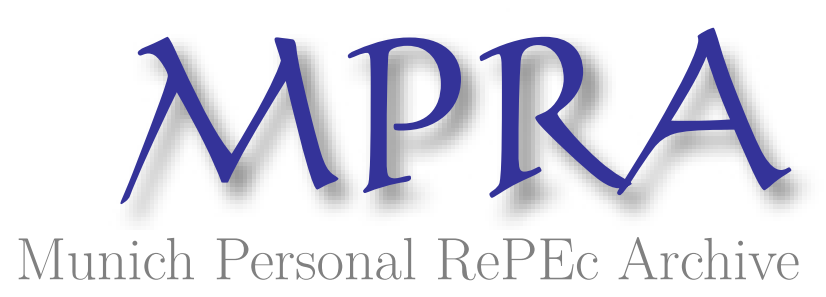

\title{
Trade imbalance in international message telephone services
}

\author{
Alleman, James and Madden, Gary G and Savage, Scott J \\ Interdisciplinary Telecommunications Department, University of \\ Colorado, Boulder, USA, Curtin University of Technology, Perth, \\ Australia, Curtin University of Technology, School of Economics and \\ Finance, Perth WA 6845, Australia
}

2000

Online at https://mpra.ub.uni-muenchen.de/11157/

MPRA Paper No. 11157, posted 19 Oct 2008 07:08 UTC 


\title{
Trade imbalance in international message telephone services
}

\author{
JAMES ALLEMAN, GARY MADDEN* and SCOTT J. SAVAGE*
}

Interdisciplinary Telecommunications Program, University of Colorado at Boulder, Engineering Center OT 343, Campus Box 530, Boulder, Colorado 80309-0530, USA and *Communications Economics Research Program, School of Economics and Finance, Curtin University of Technology, GPO Box U1987, Perth, Western Australia 6845

An econometric model is estimated to identify determinants of trade imbalance in international message telephone services markets. Results indicate that asymmetric market structure is important in explaining bilateral market imbalances for high income country pairs. For low and high income country pairs, GDP per capita is the dominant cause of traffic imbalances. The findings suggest that telecommunications liberalization policies are effective in reducing distortions in international traffic flows and settlement payments. However, liberalization should be accompanied by developmental programmes that enhance income per capita and telecommunications network investment in developing countries. Such programmes may be effective in providing a more equitable distribution of the gains from telecommunications reform across countries.

\section{INTR ODUCTION}

Telecommunications traffic is an important production input for information intensive sectors, and its economically efficient delivery provides a basis for competitive advantage. Between 1986 and 1995 world international message telephone services (IMTS) traffic increased by 12.9 per cent per annum, with total retail revenues of 53 billion United States Dollars (US\$) in 1995 (International Telecommunications Union (ITU) 1997a). Such services are traditionally jointly provided by publicly-owned monopolies who connect their local networks to designated international gateways. Bilateral market cost sharing agreements between countries are arranged through the international accounting rate system. The accounting rate is the basic 'unit of account' from which international settlement payments are calculated. A carrier's accounting rate share, the settlement rate, determines the amount the carrier must pay to access another country's network. When settlement rates are equal for outgoing and incoming calls, and outgoing is greater (less) than incoming traffic, the home country is a net importer (exporter) of telephone traffic and makes (receives) a settlement payment to (from) the foreign country. In 1995, the amount paid by carriers to settle IMTS traffic imbalances was USD28 billion (ITU, 1997a).

In the immediate post-war period the accounting rate system provided a reasonable basis for international telecommunications pricing and carrier settlements. Bilateral traffic flows were generally balanced and retail prices (collection rates) uniform. This stable environment began to change in the 1980s with the erosion of natural monopoly through rapid technological change, and the realization that competition and private ownership are more likely to increase efficiency and provide lower prices (Oum and Zhang, 1995; Snow, 1995; Madden and Savage, 1997; Spiller and Cardilli, 1997; Waverman and Sirel, 1997). The 1984 AT\&T divestiture and privatization of British Telecom led the movement away from the traditional model of monopoly supply by stated-owned carriers. By

† Corresponding author. E-mail: savages@cbs.edu.au 
1996, 13 countries had permitted facilities-based competition in the provision of IMTS, and 44 publicly owned carriers had been privatized, raising US\$159 billion (ITU, 1997a). ${ }^{1}$

Whilst technological advance has reduced the costs of providing international services, the full extent of the cost reductions are generally not reflected in lower collection rates. Ergas and Patterson (1991), Alleman and Sorce (1998) and Frieden (1997) argued that the accounting rate system, and asymmetric market structures on bilateral markets, impose little discipline on monopoly carriers to pass on cost reductions. ${ }^{2}$ Accordingly, collection rates have diverged between low price countries that pursue liberalization policies, and those which have not. Collection rate reductions by low price countries such as the United States (US) have increased their outgoing traffic relative to incoming traffic, and provided high price countries with increased settlement payments. This has occurred as users in low price countries respond to declining collection rates, and indirectly, as a result of substitution between the higher price incoming traffic and lower price outgoing traffic (Larson et al., 1990; Ergas and Patterson, 1991; Sandback, 1996). ${ }^{3}$

Increased outgoing traffic not only worsens the deficit nation's trade balance through increased settlement payments but potentially transfer rents to monopoly countries. These rents are the difference between the settlement rate (the originating carrier's payment to access the foreign country's local exchange network) and the actual cost incurred by the foreign carrier in terminating the call. Nations with liberalized telecommunications markets that have experienced deficits in 1995 are Australia, Japan, Sweden and the US. The largest deficit has occurred in the US. Between 1982 and 1995, settlement payments from US to foreign carriers increased 16 per cent per annum. The 1995 net settlement payment of US\$4.94 billion accounted for $4.75 \%$ of the total US trade deficit in goods and services (International Monetary Fund (IMF), 1996; Federal Communications Commission (FCC), 1997a). Both the FCC (1996, 1997b) and World Trade Organisation (WTO, 1997) have called for the opening of telecommunications markets to private and foreign investors, and increased competition in the delivery of local, long-distance and international services. Such policies are intended to promote price competition and productive efficiency. Collection and settlement rates that better reflect service provision costs reduce the rents within international telecommunications pricing and so alleviate distortions in traffic flows (and settlement payments).

Several studies argue that competition and collection rate differentials alone do not explain traffic imbalances. First, Cheong and Mullins (1991) showed that collection rate differentials were not strongly correlated with US traffic deficits and argued that Australia, whilst having no facilities-based competition in 1991, had an imbalance proportionately equivalent to the US. ITU (1996) data show that Finland, New Zealand and the Philippines had traffic surpluses in 1995 (despite facilities-based competition), whilst the monopoly countries Cyprus, Qatar, Luxembourg and Switzerland incurred traffic deficits (ITU, 1996; TeleGeography Inc., 1997). Second, Cheong and Mullins and the ITU (1994) argued economic development, as measured by income per capita, is also important in stimulating outgoing traffic and so affects IMTS trade imbalances. This finding suggests that policies which promote both economic and telecommunications network development may provide a more effective and equitable means of stimulating traffic from low income countries to high income countries. ${ }^{4}$ These remarks are anticipated by Dr Gautam Kaji (1996, p. 5), Managing Director of the World Bank:

The World Bank Group think the gains from telecommunications reform are big, and that the reforms are inevitable. But what is not inevitable is the way in which the reforms happen, and this will affect the distribution of the gains across countries. This of course, goes to the heart of the concerns of those who fear that the outcome of these negotiations will be to enable the rich countries to exploit the poor countries.

This study empirically identifies the determinants of IMTS trade imbalances. An econometric model is estimated using

\footnotetext{
${ }^{1}$ Facilities-based carriers have their own transmission capacity.

${ }^{2}$ Asymmetric market structure evolves from asymmetric regulation, that is, carriers in the domestic and foreign ends are subject to different regulatory environments (Schankerman, 1996). This study defines regulatory restraint in terms of competition (measured by the number of carriers) and type of ownership, at both the domestic and foreign end of a bilateral market. For example, asymmetric market structure may arise because there is a monopoly carrier at the domestic end of the bilateral market, and several carriers at the foreign end. Alternatively, asymmetric market structure can be used to describe markets where the domestic carrier is publicly owned, whilst the foreign carrier(s) is open to private ownership.

${ }^{3}$ Substitution occurs through callback operators supplying a US dial tone to conumers wishing to place a call to the US, calling parties in high price countries making a short call requesting to be called back, and reverse charge calling card services.

${ }^{4}$ Settlement rate revenue may be used to upgrade developing country networks. However, the distribution of revenues follows no explicit principle of equity or need. For example, in 1995 several OECD countries, including Canada, Japan, and South Korea, received netsettlement payments in excess of US\$100 million. By contrast, sub-Saharan Africa as a whole received just US\$125 million, or $2 \%$ of total settlement payments (ITU, 1997a). Targeted assistance programmes may be more effective in enhancing infrastructure investment and stimulating usage in these countries.
} 
annual data for 82 countries for the period 1991 through 1995. Model estimates isolate the effect of collection rates, market structure, and national income on traffic deficits. Low income country traffic flows are analysed separately by estimating the model for a subsample of low and high income country partners. Such analysis suggests reforms to market structure should be complemented by policies of economic development in low income countries. European Bank for Reconstruction and Development (EBR D; 1995) and World Bank programmes that enhance income per capita and facilitate telecommunications infrastructure investment will ultimately lead to increased outgoing traffic from low income countries (see Kaji, 1996; Wellenius and Stern, 1996). The paper is organized as follows. Section II reviews the telecommunications literature on the determinants of traffic deficits. An econometric model, and the data used for estimation, are described in Section III. Estimation results are reported in Section IV. Section V contains concluding remarks.

\section{INTER NATIONAL TELEPHONE TR AFFIC DEFICITS}

Empirical and econometric studies of international telephone traffic flows are typically based on telephone demand functions, and concerned with quantifying the relationship between traffic and collection rates, and traffic and income. A general indication of the relationships between collection rates and IMTS imbalance, and national income and IMTS imbalance, are found in Figs 1 and 2. Both figures suggest that imbalances are inversely related to differences in collection rates, and positively related to differences in national income.

Ergas and Patterson (1991) observed a large and growing imbalance between US outgoing and incoming telephone traffic. They found, for the period 1985 to 1988, that collection rates for the US were generally lower than those of their foreign counterparts. Ergas and Patterson argued that increased competition among US carriers led to collection rate reductions which stimulated US outgoing traffic. Favourable traffic imbalances and sticky collection rates are especially noticeable in developing countries. The FCC (1992) examined 90 US bilateral markets in 1991 and found average US outgoing collection rates $\left(c r_{\mathrm{O}}\right)$ were approximately half the incoming collection rate $\left(c r_{\mathrm{I}}\right)$. The Commission also suggested that the disparity in collection rates was due to greater price competition arising from US liberalization. ${ }^{5}$

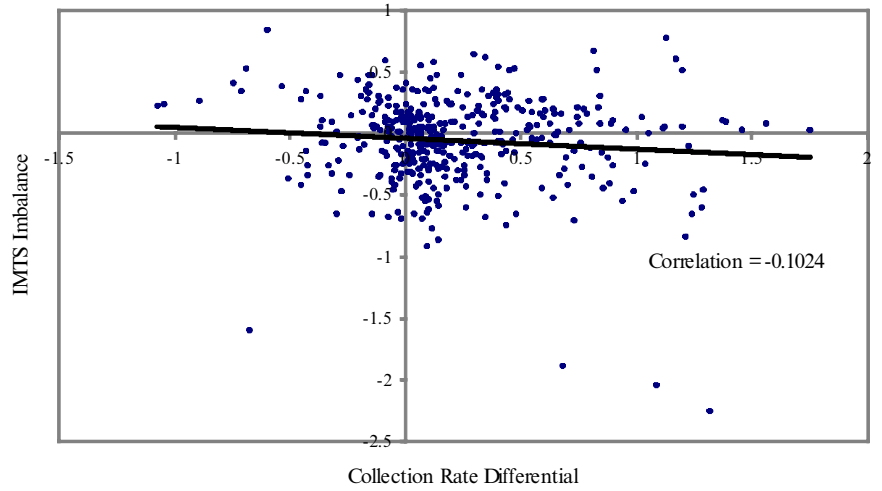

Fig. 1. IMTS and collection rates

Note: IMTS imbalance is the log of minutes of outgoing traffic less the $\log$ of minutes of incoming traffic. Collection rate differential is the $\log$ of the (per-minute) outgoing collection rate less the log of the (per-minute) incoming collection rate. Sample consists of 82 bilateral markets for the period 1991 through 1995 (see Appendix for description of bilateral markets).

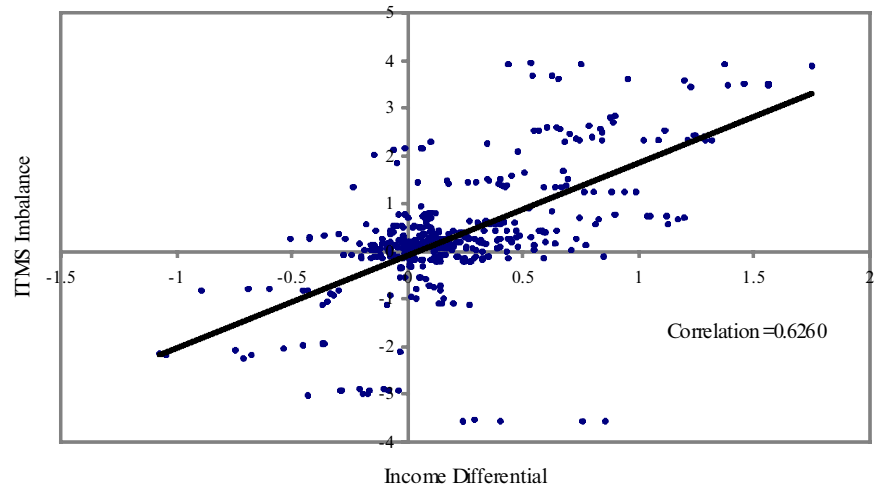

Fig. 2. IMTS and income

Note: IMTS imbalance is the log of minutes of outgoing traffic less the log of minutes of incoming traffic. Income differential is the log of GDP per capita for the outgoing country less the log of GDP per capita for the incoming country. Sample consists of 82 bilateral markets for the period 1991 through 1995 (see Appendix for description of bilateral markets).

Conversely, Cheong and Mullins (1991) argued that US traffic deficits were caused by differences in country incomes. They estimated an econometric model with traffic imbalances expressed as a function of relative income (difference between US and foreign incomes) and relative prices (difference between US and foreign collection rates). These results show US traffic deficits are positively related to relative income and not related to relative prices. Cheong and Mullins argued that international traffic is insensitive to collection rates since most of this traffic is business related. ${ }^{6}$ Given the model's low explanatory

\footnotetext{
${ }^{5}$ A declining block rate structure also gives US callers an incentive to call for longer durations as the average per-minute call change declines with length.

${ }^{6}$ See Bewley and Fiebig (1988), and Taylor (1994).
} 
power, Cheong and Mullins concluded that the growing US deficit may be due to socioeconomic and cultural differences not captured in the model.

Acton and Vogelsang (1992) employed point-to-point demand models to examine call reversion between the US and 17 Western European countries for the period 1979 through 1986. Point-to-point models allow calls in one direction to affect return calls through reversion and reciprocity (Larson et al., 1990). Reversion suggests outgoing call traffic $\left(Q_{\mathrm{O}}\right)$ and incoming call traffic $\left(Q_{\mathrm{I}}\right)$ volumes are substitutes, or $\mathrm{d} Q_{\mathrm{O}} / \mathrm{d} Q_{\mathrm{I}}<0$, which implies $\mathrm{d} Q_{\mathrm{O}} / \mathrm{d} c r_{\mathrm{I}}>0$. Reciprocity suggests outgoing and incoming calls are complimentary, that is, $\mathrm{d} Q_{\mathrm{O}} / \mathrm{d} Q_{\mathrm{I}}>0$ and $\mathrm{d} Q_{\mathrm{O}} / \mathrm{d} c r_{\mathrm{I}}<0$. Model estimates indicated no cross-price effect $\left(\mathrm{d} Q_{\mathrm{O}} / \mathrm{d} c r_{\mathrm{I}}=0\right)$, that is, neither reversion nor reciprocity motivations are apparent in aggregate traffic flows. Acton and Vogelsang noted that because of transaction costs, call reversion will occur only when the outgoing and incoming collection rate differential is large. Once this threshold is reached, consumers in high price countries will reoriginate calls from low price countries. ${ }^{7}$

Sandback (1996) accounted for reversion and transaction costs by estimating a point-to-point model for outgoing traffic which included the price arguments, outgoing collection rates, relative collection rates, and a collection rate differential which took effect when the difference between foreign and domestic country collection rates exceeds a transaction cost threshold. Using data from 154 OECD bilateral telephone markets, Sandback found relative collection rates and the collection rate differential terms have the impacts expected on outgoing traffic but this affect is not significant. Sandback suggested that there is some evidence to support the callback effect where arbitrage opportunities exceed a threshold of US\$0.90 a minute.

A separate body of game-theoretic work considers the strategic interaction between carriers in setting collection and accounting rates, and in turn, examine the impact of these rates on telephone demand imbalances. Hakim and Lu (1993, 1994) developed a model of bilateral monopoly service provision. By modelling the strategic interaction between carriers they examined how price setting and technological disparities affect demand imbalances. Following Larson et al. (1990) and Acton and Vogelsang (1992), they accounted for reversion and reciprocity. They found, when allowing for a negotiable settlement rate share, technological improvement by a domestic monopolist led to reduced collection rates, increased demand for outgoing calls, and a growing traffic imbalance. ${ }^{8} \mathrm{~A}$ traffic deficit entices the home country to revise the settlement rate down in order to minimize the settlement out-payment. This result is consistent with the behaviour of high income countries whom, with stronger international call demand and more advanced technology, seek lower settlement rates.

Yun et al. (1997) extended this analysis and allowed competition at either end of the bilateral market. They found increased domestic competition lowered the outgoing collection rate, and exacerbated traffic imbalance. Increased competition in the foreign country mitigates bilateral traffic imbalance. This result supports the findings of Ergas and Patterson (1991) and the FCC (1992). However, Yun et al. (1997) noted as the number of competitors approaches infinity, a high accounting rate reduced traffic imbalances. This suggests that asymmetric market structure (and the accounting rate system) are not the sole cause of traffic imbalances in countries with liberalized telecommunications sectors. Imbalances may result from longer term cultural and socioeconomic factors. This is reflected in studies of international telephone demand. Lago (1970), Yatrakis (1972), Rea and Lage (1978), Acton and Vogelsang (1992), showed that national income is a determinant of demand, whilst Rohlfs (1974) suggested point-to-point models should include variables that approximate the community of interest between the calling parties (countries) considered. The larger is the community of interest, the greater is telephone traffic.

\section{ECONOMETR IC MODEL AND DATA}

The preceding section implies the following general form equation for IMTS imbalance $\left(T_{\mathrm{B}}\right)$ between the domestic country $D$ and foreign country $F$ :

$$
T_{\mathrm{B}}=T_{\mathrm{B}}\left(P_{\mathrm{O}}, P_{\mathrm{I}}, M S_{\mathrm{O}}, M S_{\mathrm{I}}, Y_{\mathrm{O}}, Y_{\mathrm{I}}, Z_{\mathrm{O}}, Z_{\mathrm{I}}\right)
$$

where $P_{\mathrm{O}}$ is the collection rate for a call from $D$ to $F, P_{\mathrm{I}}$ is the collection rate for a call from $F$ to $D, M S_{\mathrm{O}}$ is a vector describing the market structure (in terms of competition and ownership) of $D$ 's international IMTS sector, $M S_{\mathrm{I}}$ is a vector describing the market structure of $F$ 's international IMTS sector, $Y_{\mathrm{O}}$ is country $D$ income, $Y_{\mathrm{I}}$ is country $F$ income, $Z_{\mathrm{O}}$ is a vector of country $D$ factors approximating the community of interest between $D$ and $F$, and $Z_{\text {I }}$ is country $F$ community of interest factors.

\footnotetext{
${ }^{7}$ Sandback (1996) argues that moderate collection rate differentials have little effect since callback operators cannot recover their own costs, and still provide a price discount to compensate customers for callback inconvenience an overcome customer inertia.

${ }^{8}$ In practice, most bilateral markets are governed by the 50:50 settlement rate share rule. The rule requires all carriers to accept the same accounting rate for a particular bilateral market, and that the accounting rate is divided equally (so that settlement rates are the same for terminating incoming calls and originating outgoing calls). This arrangement removed the incentive for a single carrier in a competitive market to accept less favourable conditions from the foreign monopolist as they will apply to all carriers (Cave, 1995).
} 
Following Cheong and Mullins (1991) and Sandback (1996) we assume that it is relativities between independent variables which affect $T_{\mathrm{B}}$. The econometric model for IMTS trade imbalance on bilateral market $i$ at time $t$, in log-linear form, is:

$$
\begin{aligned}
\log \mathrm{T}_{\mathrm{B} i t}= & \alpha_{0}+\alpha_{1} \log \left(P_{\mathrm{O}} / P_{\mathrm{I}}\right)_{i t}+\alpha_{2} \log \left(M_{\mathrm{O}} / M_{\mathrm{I}}\right)_{i t} \\
& +\alpha_{3} \log \left(Y_{\mathrm{O}} / Y_{\mathrm{I}}\right)_{i t}+\alpha_{4} \log \left(Z_{\mathrm{O}} / Z_{\mathrm{I}}\right)_{i t}+\varepsilon_{i t}
\end{aligned}
$$

for $i=1, \ldots, n$, and $t=1, \ldots, T$, where $\alpha_{0}$ is an intercept, $\alpha_{1}$ through $\alpha_{4}$ are elasticities, and $\varepsilon_{i t}$ is a white noise disturbance term.

With pooled time-series, cross-sectional data some of the variation in $T_{\mathrm{B}}$ may be caused by differences in factor prices, service quality and technology between the countries forming the bilateral market. The inclusion of dummy variables for each individual bilateral market allows for different intercepts across the sample. Finally, the model is augmented to account for reversion affects as described by Acton and Vogelsang (1992) and Sandback (1996):

$$
\begin{aligned}
\log T_{\mathrm{B} i t}= & \beta_{0 i}+\beta_{1} \log \left(P_{\mathrm{O}} / P_{\mathrm{I}}\right)_{i t}+\beta_{2} \log \left(P^{*}\right)_{i t} \\
& +\beta_{3} \log \left(M_{\mathrm{O}} / M_{\mathrm{I}}\right)_{i t}+\beta_{4} \log \left(Y_{\mathrm{O}} / Y_{\mathrm{I}}\right)_{i t} \\
& +\beta_{5} \log \left(Z_{\mathrm{O}} / Z_{\mathrm{I}}\right)_{i t}+u_{i t}
\end{aligned}
$$

where $\beta_{0 i}$ is the intercept for the $i$ th bilateral market, $P^{*}$ is a measure of call reversion which comes into affect when the difference between incoming and outgoing collection rates exceeds a transactions cost threshold, $\beta_{1}$ through $\beta_{5}$ are elasticities, and $u_{i t}$ is a white noise disturbance term.

Theory suggests $\beta_{2}<0, \beta_{3}>0$ and $\beta_{5}>0$, whilst the signs for $\beta_{4}$ and $\beta_{6}$ remain an empirical question. The ability of carriers to set collection rates above cost depends on market power. Market power is in turn related to market structure, measured here by the number of facilities-based carriers and market concentration. Competition is relatively stronger in country $D$ when the number of country $D$ carriers exceeds the number of $F$ carriers, or alternatively, when $D$ market concentration is less than $F$ market concentration. Since relatively lower collection rates in country $D$ should stimulate outgoing traffic, a positive relationship is expected between $\left(M S_{\mathrm{O}} / M S_{\mathrm{I}}\right)_{1}$ and $T_{\mathrm{B}}$ when the number of carriers is used to measure competition, and a negative relationship is expected when market concentration is used as the competition proxy. Generally, privately owned carriers have an incentive to operate more efficiently than public carriers (Hensher, 1986). An increase in the private ownership share of the dominant country $D$ carrier relative to $F$ may result in lower outgoing collection rates and an increase in outgoing traffic relative to incoming traffic. A positive relationship is expected between $\left(M S_{\mathrm{O}} / M S_{\mathrm{I}}\right)_{2}$ and $T_{\mathrm{B}}$. Finally, community of interest $\left(Z_{\mathrm{O}} / Z_{\mathrm{I}}\right)$ is measured by the ratio of country $D$ and $F$ trade shares. ${ }^{9}$ There is no a priori assumptions about the sign for $\beta_{6}$.

Equation 3 is estimated on annual data for 82 international bilateral telephone markets for the period 1991 through 1995 (see Appendix for a description of bilateral markets). Bilateral telephone markets are formed from 43 countries with average GDP per capita for the period 1991 through 1995 ranging from US\$394 (India) to US\$26914 (Switzerland). By defining low income countries as economies with average GDP per capita of US\$2895 or less, and high incomes countries as economies with GDP per capita of US\$2896 or more, it is possible to construct two mutually exclusive subsamples. ${ }^{10}$ Of the 82 bilateral markets contained in the sample, 66 involve traffic flows between high income country pairs and 16 involve traffic between low and high income countries. A description of the variables used for econometric estimation is provided in Table 1.

\section{ECONOMETRIC RESULTS}

Equation 3 is estimated by generalized least squares to correct for within group autocorrelation and groupwise heteroscedasticity. ${ }^{11}$ Estimates are reported in Table 2 for the full sample of 82 bilateral markets. Table 3 includes estimates for the subsample of 66 markets containing high income country pairs, and estimates for the subsample of 16 markets comprising of high and low income country pairs. Alternative facilities-based competition proxies are used in all models: (i) denotes number of carriers; and (ii) market concentration.

Full sample estimates accord with a priori expectations. The estimated coefficient for the collection rate differential

\footnotetext{
${ }^{9}$ Other community of interest measures include immigrant population, common language, market size, tourism and trade (Taylor, 1994; Sandback, 1996). Because these variables are measured in absolute terms it is difficult to isolate their individual impacts in the bidirectional traffic model (3).

${ }^{10}$ Our definition is based on standard ITU and World Bank classifications. The ITU (1997c) classify economies into the following groups: low income, economies with GDP per capita of US\$725 or less; lower-middle income, economies with GDP per capita of more than US\$726 and less than US\$2895: upper-middle income, economies with GDP per capita of more than US\$2896 and less than US\$8995: and high income, economies with GDP per capita of US\$8956 or more.

${ }^{11}$ Diagnostic testing of ordinary least squares residuals suggests the presence of autocorrelation and heteroscedasticity. A Hausman test indicates the use of individual intercept terms to capture differences at the bilateral market level is consistent with these data. Estimates of individual intercept terms for all models are available on request from the authors.
} 
Table 1. Variable description

\begin{tabular}{|c|c|}
\hline$T_{\mathrm{B}}$ & IMTS trade imbalance. Minutes of outgoing IMTS from $D$ to $F$ divided by minutes of incoming IMTS from $F$ to $D$. \\
\hline$\left(P_{\mathrm{O}} / P_{\mathrm{I}}\right)$ & $\begin{array}{l}\text { Collection rate differential. Peak rate collection rate (US\$) per minute for a call from country } D \text { to } F \text { divided by the peak } \\
\text { rate collection rate (US\$) per minute for a call from } F \text { to } D \text {. }\end{array}$ \\
\hline$\left(P^{*}\right)$ & $\begin{array}{l}\text { Call reversion. A variable that equals }\left(P_{\mathrm{I}} / P_{\mathrm{O}}\right) \text { when }\left(P_{\mathrm{I}} / P_{\mathrm{O}}\right) \text { is greater than } 0.2 \text {; and zero otherwise. Where }\left(P_{\mathrm{I}} / P_{\mathrm{O}}\right) \text { is } \\
\text { the peak rate collection rate (US } \$ \text { ) per minute for a call from country } F \text { to } D \text { divided by the peak rate collection rate } \\
\text { (US } \$ \text { ) per minute for a call from } D \text { to } F \text {, less US } \$ 0.2 \text {. }\end{array}$ \\
\hline$\left(M S_{\mathrm{O}} / M S_{\mathrm{I}}\right)_{1}$ & $\begin{array}{l}\text { Asymmetric market structure - facilities based carriers. The number of country } D \text { facilities-based carriers supplying } \\
\text { IMTS divided by the number of country } F \text { facilities-based carriers supplying IMTS. } \\
\text { Asymmetric market structure - market concentration. The country } D \text { dominant facilities-based carrier's share of IMTS } \\
\text { from } D \text { to } F \text { divided by the country } F \text { dominant facilities-based carrier's share of IMTS from } F \text { to } D .{ }^{\text {a }}\end{array}$ \\
\hline$\left(M S_{\mathrm{O}} / M S_{\mathrm{I}}\right)_{2}$ & $\begin{array}{l}\text { Asymmetric market structure-private ownership share. One plus the private ownership share of the dominant country } D \\
\text { facilities-based carrier, divided by one plus the private ownership share of the dominant country } F \text { facilities-based } \\
\text { carrier. }\end{array}$ \\
\hline$\left(Y_{\mathrm{O}} / Y_{\mathrm{I}}\right)$ & $\begin{array}{l}\text { Income differential. Country D GDP (constant } 1987 \text { US\$) per capita divided by country F GDP (constant } 1987 \text { US\$) } \\
\text { per capita. }\end{array}$ \\
\hline$\left(Z_{\mathrm{O}} / Z_{\mathrm{I}}\right)$ & Community of interest. The share of country $D$ world trade with $F$ divided by the share of country $F$ world trade with $D$. \\
\hline
\end{tabular}

Source: FCC (1992), Council for Economic Planning and Development (CEPD) (1997), ITU (1996), IMF (1997), TeleGeography Inc. (1997), World Bank (1997).

Note: ${ }^{\text {a }}$ When carrier specific traffic data are unavailable for particular markets, the dominant carrier's share of world outgoing traffic is used as a proxy for bilateral market share.

Table 2. Full sample estimates

\begin{tabular}{|c|c|c|c|}
\hline $\begin{array}{l}\text { Dependent variable: } \\
\text { IMTS trade inbalance }\end{array}$ & $\log T_{\mathrm{B}}$ & $\begin{array}{l}(\mathrm{i}) \\
(n=82)\end{array}$ & $\begin{array}{l}(\mathrm{ii}) \\
(n=82)\end{array}$ \\
\hline Collection rate differential & $\log \left(P_{\mathrm{O}} / P_{\mathrm{I}}\right)$ & $\begin{array}{l}-0.031^{\mathrm{a}} \\
(-3.132)\end{array}$ & $\begin{array}{l}-0.028^{\mathrm{a}} \\
(-2.675)\end{array}$ \\
\hline Call reversion & $\log \left(P^{*}\right)$ & $\begin{array}{l}0.005^{\mathrm{b}} \\
(1.972)\end{array}$ & $\begin{array}{c}0.001 \\
(0.430)\end{array}$ \\
\hline $\begin{array}{l}\text { Asymmetric market structure } \\
\text { Facilities-based carriers }\end{array}$ & $\log \left(M S_{\mathrm{O}} / M S_{\mathrm{I}}\right)_{1}$ & $\begin{array}{r}0.075^{\mathrm{a}} \\
(4.245)\end{array}$ & - \\
\hline Market concentration & & - & $\begin{array}{l}-0.500^{\mathrm{a}} \\
(-11.26)\end{array}$ \\
\hline $\begin{array}{l}\text { Asymmetric market structure } \\
\text { Private ownership share }\end{array}$ & $\log \left(M S_{\mathrm{O}} / M S_{\mathrm{I}}\right)_{2}$ & $\begin{array}{r}0.325^{\mathrm{a}} \\
(15.86)\end{array}$ & $\begin{array}{r}0.390^{\mathrm{a}} \\
(8.424)\end{array}$ \\
\hline Income differential & $\log \left(Y_{\mathrm{O}} / \mathrm{Y}_{\mathrm{I}}\right)$ & $\begin{array}{l}0.099^{\mathrm{a}} \\
(3.534)\end{array}$ & $\begin{array}{c}0.062 \\
(1.757)\end{array}$ \\
\hline $\begin{array}{l}\text { Community of interest } \\
\text { Trade }\end{array}$ & $\log \left(Z_{\mathrm{O}} / Z_{\mathrm{I}}\right)$ & $\begin{array}{l}0.042 \\
(1.297)\end{array}$ & $\begin{array}{c}0.016 \\
(0.473)\end{array}$ \\
\hline$n T$ & & 410 & 410 \\
\hline Buse $R^{2}$ & & 0.99 & 0.99 \\
\hline$F$-test & & $10.78^{\mathrm{a}}$ & $13.18^{\mathrm{a}}$ \\
\hline
\end{tabular}

Note: ${ }^{\mathrm{a}}$ Denotes significance at the $1 \%$ level; ${ }^{\mathrm{b}}$ denotes significance at the $5 \%$ level; $t$-ratio in parentheses; $F$-test tests that the coefficients on the $(n-1)$ individual bilateral market dummy variables are equal to zero.

is consistent with the hypothesis that a reduction (increase) in country $D$ outgoing (incoming) collection rates stimulates outgoing (incoming) calls which are in turn substituted for incoming (outgoing) calls. Similarly, the significant positive sign for call reversion suggests a collection rate differential above a transaction cost threshold of US\$0.20 is sufficient to promote further substitution between outgoing and incoming calls. ${ }^{12}$ Both coefficients

\footnotetext{
${ }^{12}$ All models were estimated with call reversion variable constructed from transaction cost thresholds of US\$0.10, US\$0.20, US\$0.30, and US\$0.40, respectively. Only the threshold of US\$0.20 proved significant.
} 


\begin{tabular}{|c|c|c|c|c|c|}
\hline $\begin{array}{l}\text { Dependent variable: } \\
\text { IMTS trade imbalance }\end{array}$ & $\log T_{\mathrm{B}}$ & $\begin{array}{l}(\mathrm{i}) \\
\text { High } \\
\text { income } \\
\text { country } \\
\text { pairs } \\
(n=66)\end{array}$ & $\begin{array}{l}\text { (ii) } \\
\text { High } \\
\text { income } \\
\text { country } \\
\text { pairs } \\
(n=66)\end{array}$ & $\begin{array}{l}\text { (i) } \\
\text { High and } \\
\text { low income } \\
\text { country } \\
\text { pairs } \\
(n=16)\end{array}$ & $\begin{array}{l}\text { (ii) } \\
\text { High and } \\
\text { low income } \\
\text { country } \\
\text { pairs } \\
(n=16)\end{array}$ \\
\hline Collection rate differential & $\log \left(P_{\mathrm{O}} / P_{\mathrm{I}}\right)$ & $\begin{array}{c}-0.001 \\
(-0.117)\end{array}$ & $\begin{array}{l}-0.023^{\mathrm{a}} \\
(-2.517)\end{array}$ & $\begin{array}{l}-0.068 \\
(-1.309)\end{array}$ & $\begin{array}{c}-0.007 \\
(-0.169)\end{array}$ \\
\hline Call reversion & $\log \left(P^{*}\right)$ & $\begin{array}{c}0.004 \\
(1.511)\end{array}$ & $\begin{array}{c}0.001 \\
(0.585)\end{array}$ & $\begin{array}{c}0.015 \\
(1.131)\end{array}$ & $\begin{array}{c}0.014 \\
(1.007)\end{array}$ \\
\hline $\begin{array}{l}\text { Asymmetric market structure } \\
\text { Facilities-based carriers }\end{array}$ & $\log \left(M S_{\mathrm{O}} / M S_{\mathrm{I}}\right)_{1}$ & $\begin{array}{l}0.039^{\mathrm{b}} \\
(1.972)\end{array}$ & - & $\begin{array}{l}-0.090 \\
(-0.947)\end{array}$ & - \\
\hline Market concentration & & - & $\begin{array}{r}-0.429^{\mathrm{a}} \\
(-10.41)\end{array}$ & - & $\begin{array}{l}-0.762^{\mathrm{a}} \\
(-6.416)\end{array}$ \\
\hline $\begin{array}{l}\text { Asymmetric market structure } \\
\text { Private ownership share }\end{array}$ & $\log \left(M S_{\mathrm{O}} / M S_{\mathrm{I}}\right)_{2}$ & $\begin{array}{l}0.314^{\mathrm{a}} \\
(15.62)\end{array}$ & $\begin{array}{r}0.432^{\mathrm{a}} \\
(8.922)\end{array}$ & $\begin{array}{l}0.250^{\mathrm{a}} \\
(2.794)\end{array}$ & $\begin{array}{l}0.240^{\mathrm{a}} \\
(2.530)\end{array}$ \\
\hline Income differential & $\log \left(Y_{\mathrm{O}} / Y_{\mathrm{I}}\right)$ & $\begin{array}{l}-0.036 \\
(-1.068)\end{array}$ & $\begin{array}{l}-0.058 \\
(-1.804)\end{array}$ & $\begin{array}{l}0.824^{\mathrm{a}} \\
(6.360)\end{array}$ & $\begin{array}{r}0.712^{\mathrm{a}} \\
(6.289)\end{array}$ \\
\hline $\begin{array}{l}\text { Community of interest } \\
\text { Trade }\end{array}$ & $\log \left(Z_{\mathrm{O}} / \mathrm{Z}_{\mathrm{I}}\right)$ & $\begin{array}{c}0.068 \\
(1.705)\end{array}$ & $\begin{array}{c}0.057 \\
(1.659)\end{array}$ & $\begin{array}{l}-0.033 \\
(-0.589)\end{array}$ & $\begin{array}{l}-0.029 \\
(-0.495)\end{array}$ \\
\hline$n T$ & & 330 & 330 & 80 & 80 \\
\hline Buse $R^{2}$ & & 0.99 & 0.99 & 0.99 & 0.99 \\
\hline$F$-test & & $12.80^{\mathrm{a}}$ & $15.31^{\mathrm{a}}$ & $7.800^{\mathrm{a}}$ & $9.720^{\mathrm{a}}$ \\
\hline
\end{tabular}

Note: ${ }^{\mathrm{a}}$ Denotes significance at the $1 \%$ level; ${ }^{\mathrm{b}}$ denotes significance at the $5 \%$ level; $t$-ratio in parentheses; $F$-test tests that the coefficients on the $(n-1)$ individual bilateral market dummy variables are equal to zero.

for the asymmetric market structure variables are significant and have the expected signs. The reported positive coefficient for facilities-based carriers $\left(M S_{\mathrm{O}} / M S_{\mathrm{I}}\right)_{1}$ indicates that the entry of new carriers in a deficit (surplus) nation will increase (decrease) their traffic deficit (surplus). That is, as the number of country $D$ carriers providing outgoing call services increases relative to $F$, collection rate differentials are reduced, and outgoing traffic increases relative to incoming traffic. Similarly, the positive coefficient on private ownership share $\left(M S_{\mathrm{O}} / M S_{\mathrm{I}}\right)_{2}$ indicates that domestic carrier conduct responds to the type of ownership. For instance, an increase in private ownership of the dominant carrier in a deficit nation may lead to efficiency gains which are passed on to consumers through lower collection rates, which in turn, leads to increased outgoing traffic. Model estimates also show that outgoing (relative to incoming) traffic is higher the greater is the outgoing country's GDP per capita relative to its bilateral market country partner. The result from model (ii), using market concentration as the competition proxy, are qualitatively similar to those of (a). The coefficient estimate for collection rate differentials are negative, however, the reversion variable has no impact. The expected coefficient sign on market concentration is negative and suggests that increased competition in $D$ relative to $F$ (as reflected in declining market share for the dominant carrier) enhances collection rate differentials and increases outgoing traffic relative to incoming traffic.

Estimated coefficients for both the collection rate and income differentials are insignificant for the subsample of high income country pairs. However, price affects remain influential through both call reversion and the asymmetric market structure variables. Coefficients for facilities-based carriers, market concentration, and private ownership share are correctly signed and statistically significant.

Collection rate differentials and call reversion are not significant in the subsample of low and high income country pairs. In (i) market structure affects on IMTS imbalance are not evident through facilities-based competition but remain strong in private ownership share. In (ii), market structure affects IMTS imbalance through market concentration and private ownership. The coefficients on private ownership share are significant and relatively stable across all models. This is not surprising since private ownership may be proxying for potential competition, given that telecommunications reforms usually include privatisation as a precursor to the introduction of competition. Any increase in the level of private ownership at either end of the market may provide a signal to domestic and foreign carriers that increased competition for market share may be forthcoming. Finally, the estimated coefficient for income is large and significant in (i) and (ii) and suggests that income 
differences are the dominant source of traffic imbalance in markets comprising of low and high income country partners. Consider a low income country which has a traffic surplus with a high income country. A per cent increase in this country's GDP per capita would stimulate outgoing traffic and result in a $0.824(0.712)$ per cent reduction in the high income country's traffic deficit. High income countries are likely to have a more extensive level of network development and a greater propensity for new investment which leads to cost efficiencies. Thus, lower collection rates would be generally expected in high income countries.

\section{CONCLUSIONS}

The accounting rate system and concentrated telecommunications markets have contributed to the distortion in IMTS settlement payments. Pressure is building within the telecommunications community to revise the current system of settlement payments, and to promote greater competition between carriers (FCC, 1997b, 1996; ITU, 1997b; WTO, 1997). This pressure has come mainly from carriers and government agencies in those countries which make substantial settlement payments to countries that are net-exporters of IMTS.

This study develops an econometric model to empirically identify determinants of IMTS imbalance. Model results show that collection rate differentials and asymmetric market structure are important determinants of imbalance in bilateral markets comprising of high income country partners. Therefore, FCC (1996, 1997b) and WTO (1997) initiatives to achieve efficient pricing through reforms to market structure should be most effective in stimulating traffic from high income countries, traditionally served by publicly owned monopolies. GDP per capita appears to be the dominant source of traffic imbalance in markets comprising of low and high income country partners. Economic development policies that enhance income per capita and telecommunications network investment may be more appropriate mechanisms for stimulating outgoing traffic from developing countries. Here, market orientated liberalization policies should be accompanied by development programmes such as those advocated by the EBRD (1995) and World Bank.

Finally, traffic imbalance between country partners only concerns economists because of inefficient pricing. When collection rates and settlement rates reflect the cost of service provision, the issue of imbalance issue becomes less relevant. In this first-best world, economic rents would be dissipated and relative prices would provide correct signals to IMTS users. In a second-best world, the choice of mechanisms for achieving an efficient and equitable outcome for developing countries is clearly important. One such mechanism would require a careful blend of increased market liberalization in high income countries, along with targeted assistance programmes in developing countries. In the words of Gautam Kaji (1996, p. 5):

We (the World Bank Group) see considerable scope for the protection of developing country interests in the competition among the developed countries to supply their markets. As a critical mass of developed countries liberalizes their own markets, developing countries will benefit from competition among telecommunications suppliers and the threat of unfair use of market power will be minimized.

\section{ACKNOWLEDGEMENTS}

The authors would like to thank Antonio Leite, Dimitri Ypsilanti and participants at the Twelfth Biennial Conference of the International Telecommunications Society, Stockholm, Sweden, 21-24 June, 1998, for comments. Data support from the FCC and ITU is gratefully acknowledged, as is research assistance by Craig Tipping. Any opinions, findings or conclusions expressed in this paper are those of the authors and do not reflect the views of named institutions and individuals.

\section{R EFER ENCES}

Acton, J. and Vogelsang, I. (1992) Telephone demand over the Atlantic: evidence from country-pair data, The Journal of Industrial Economics, 40, 1-19.

Alleman, J. and Sorce, B. (1998) International settlements: a time for a change, in Telecommunications Transformation: Technology, Strategy and Policy (Eds) E. Behlir and S. L. Levin, ISO Press, Amsterdam, pp. 189-201.

Bewley, R. and Fiebig, D. (1988) Estimation of price elasticities for an international telephone demand model, Journal of Industrial Economics, 36, 393-409

Cave, M. (1995) The economic consequence of the introduction and regulation of international resale of telecommunications services, in Beyond Competition: The Future of Communications (Ed.) D. Lamberton, North-Holland, Amsterdam, pp. 227-47.

CEPD (1997) Taiwan Statistical Data Book, Council for Economic Planning and Development, Taipei.

Cheong, K. and Mullins, M. (1991) International telephone service imbalances: accounting rates and regulatory policy, Telecommunications Policy, 15, 107-18.

EBRD (1995) Transition Report Update, European Bank for Reconstruction and Development, London.

Ergas, H. and Patterson, P. (1991) International telecommunications settlement arrangements: an unsustainable inheritance, Telecommunications Policy, 15, 29-48.

FCC (1992) Calling Prices for International Message Telephone Service Between the United States and Other Countries, Federal Communications Division, Washington.

FCC (1996) Policy Statement on International Accounting Rate Reform, 96-37, 31 January, Federal Communications Division, Washington.

FCC (1997a) Trends in the US International Telecommunications Industry, Federal Communications Division, Washington. 
FCC (1997b) Chairman of the FCC's Speech to the Hispanic Chamber of Commerce, 17 July, Federal Communications Division, Washington.

Frieden, R. (1997) International Telecommunications Handbook, Artech House, London.

Hakim, S. R. and Lu, D. (1993) Monopolistic settlement agreements in international telecommunications, Information Economics and Policy, 5, 145-57.

Hakim, S. R. and Lu, D. (1994) Duopolistic pricing in international telecommunications, presented to the International Telecommunications Society Meeting, Sydney, July.

Hensher, D. (1986) Privatisation: an interpretative essay, Australian Economic Papers, 25, 147-74.

IMF (1996) Balance of Payments Statistics Yearbook 1996. Country Tables, International Monetary Fund, Washington.

IMF (1997) Direction of Trade Yearbook 1996, International Monetary Fund, Washington.

ITU (1994) Direction of Traffic: International Telephone Traffic, First Edition, International Telecommunications Union, Geneva.

ITU (1996) Direction of Traffic: Trends in International Telephone Tariffs, Second Edition, International Telecommunications Union, Geneva.

ITU (1997a) World Telecommunication Development Report, International Telecommunications Union, Geneva.

ITU (1997b) Report of the Informal Expert Group on International Telecommunication Settlements, International Telecommunications Union, Geneva.

ITU (1997c) Challenges to the Network: Telecoms and the Internet, International Telecommunications Union, Geneva.

Kaji, G. (1996) Trade in telecommunications services, address to an Informal Ministerial Discussion, Singapore, 9 December, The World Bank.

Lago, A. (1970) Demand forecasting models of international telecommunications and their policy implications, Journal of Industrial Economics, 19, 6-21.

Larson, A., Lehman, D. and Weisman, D. (1990) A general theory of point-to-point long distance demand, in Telecommunications Demand Modelling (Eds) A. De Fontenay, M. H. Shugard and D. S Sibley, North-Holland, Amsterdam, pp. 299-318.

Madden, G. and Savage, S. (1997) Market Structure, Competition and Pricing in United States International Telephone Services
Markets, School of Economics and Finance Discussion Paper, 98:05, Curtin University of Technology, Perth.

Oum, T. and Zhang, Y. (1995) Competition and allocative efficiency: the case of the US telephone industry, The Review of Economics and Statistics, 27, 82-96.

Rea, J. and Lage, G. (1978) Estimates of demand elasticities for international telecommunications services, Journal of Industrial Economics, 26, 1-19.

Rohlfs, J. (1974) A theory of interdependent demand for a communications service, Bell Journal of Economics and Management Science, 5, 16-37.

Sandback, J. (1996) International telephone traffic, callback and policy implications, Telecommunications Policy, 20, 507-15.

Schankerman, M. (1996) Symmetric regulation for competitive telecommunications, Information Economics and Policy, 8, 3-23.

Snow, M. (1995) The AT\&T divestiture: a 10-year retrospective, in Beyond Competition: The Future of Communications (Ed.) D. Lamberton, North-Holland, Amsterdam.

Spiller, P. and Cardilli C. (1997) The frontier of telecommunications deregulation: small countries leading the pack, Journal of Economic Perspectives, 11, 127-38.

Taylor, L. (1994) Telecommunications Demand in Theory and Practice, Second edition, Kluwer Academic Publishers, Boston.

TeleGeography Inc. (1997) TeleGeography 1996/97: Global Telecommunications Traffic Statistics and Commentary, TeleGeography Inc., Washington.

Waverman, L. and Sirel, E. (1997) European telecommunications markets on the verge of full liberalisation, Journal of Economic Perspectives, 11, 113-26.

Wellenius, B. and Stern, P. (1996) Implementing Reform in the Telecommunications Sector: Lessons from Experience, World Bank, Washington.

World Bank (1997) 1997 World Development Indicators, World Bank, Washington.

WTO (1997) The Agreement on Basic Telecommunications Services, 15 February, WTO Publications Service, Geneva.

Yatrakis, P. (1972) Determinants of the demand for international telecommunications, Telecommunications Journal, 39, 73246.

Yun, K., Choi, H. and Ahn, B. (1997) The accounting revenue division in international telecommunications conflicts and inefficiencies, Information Economics and Policy, 9, 71-92. 
IMTS traffic

million minutes

Bilateral market

\begin{tabular}{|c|c|c|c|c|c|c|c|}
\hline & \multirow[b]{2}{*}{$(1)$} & \multirow[b]{2}{*}{$(2)$} & \multirow{2}{*}{$\begin{array}{l}\text { Deficit } \\
\text { (surplus) }\end{array}$} & \\
\hline Country (1) & Country (2) & & & & (1) & (2) & High/Low ${ }^{b}$ \\
\hline Australia & $\mathrm{UK}$ & 131.26 & 102.22 & 29.04 & 13690 & 12879 & $\mathrm{HH}$ \\
\hline Australia & New Zealand & 108.10 & 109.61 & $(1.51)$ & 13690 & 11430 & $\mathrm{HH}$ \\
\hline Belgium & France & 234.37 & 202.74 & 31.63 & 16125 & 17663 & $\mathrm{HH}$ \\
\hline Belgium & UK & 87.00 & 88.50 & $(1.50)$ & 16125 & 12879 & $\mathrm{HH}$ \\
\hline Belgium & Italy & 50.86 & 47.17 & 3.69 & 16125 & 14944 & $\mathrm{HH}$ \\
\hline Canada & UK & 126.39 & 99.22 & 27.17 & 15660 & 12879 & $\mathrm{HH}$ \\
\hline Canada & France & 43.79 & 32.80 & 10.99 & 15660 & 17663 & $\mathrm{HH}$ \\
\hline Chile & US & 27.31 & 47.94 & $(20.63)$ & 2286 & 19940 & LH \\
\hline Denmark & Germany & 87.09 & 88.25 & $(1.16)$ & 21289 & 20282 & $\mathrm{HH}$ \\
\hline Denmark & Sweden & 78.48 & 88.08 & $(9.60)$ & 21289 & 19233 & $\mathrm{HH}$ \\
\hline Denmark & UK & 49.31 & 47.14 & 2.17 & 21289 & 12879 & $\mathrm{HH}$ \\
\hline Denmark & Norway & 47.43 & 51.64 & $(4.21)$ & 21289 & 23771 & $\mathrm{HH}$ \\
\hline France & Italy & 220.10 & 215.32 & 4.78 & 17663 & 14944 & $\mathrm{HH}$ \\
\hline France & Spain & 159.60 & 145.47 & 14.13 & 17663 & 8876 & $\mathrm{HH}$ \\
\hline France & Portugal & 118.68 & 49.86 & 68.82 & 17663 & 5087 & $\mathrm{HH}$ \\
\hline France & Netherlands & 84.98 & 94.39 & $(9.41)$ & 17663 & 16856 & $\mathrm{HH}$ \\
\hline Morocco & France & 54.09 & 70.12 & $(16.03)$ & 912 & 17663 & LH \\
\hline Germany & Austria & 362.16 & 324.27 & 37.90 & 20282 & 17645 & $\mathrm{HH}$ \\
\hline Germany & UK & 326.14 & 311.28 & 14.86 & 20282 & 12879 & $\mathrm{HH}$ \\
\hline Germany & France & 347.04 & 292.26 & 54.78 & 20282 & 17663 & $\mathrm{HH}$ \\
\hline Germany & Italy & 320.81 & 248.19 & 72.62 & 20282 & 14944 & $\mathrm{HH}$ \\
\hline Germany & Turkey & 322.66 & 96.10 & 226.56 & 20282 & 1806 & $\mathrm{HL}$ \\
\hline Germany & Poland & 169.01 & 92.48 & 76.54 & 20282 & 1553 & $\mathrm{HL}$ \\
\hline Germany & Spain & 138.93 & 127.34 & 11.60 & 20282 & 8876 & $\mathrm{HH}$ \\
\hline Germany & Belgium & 128.91 & 125.43 & 3.48 & 20282 & 16125 & $\mathrm{HH}$ \\
\hline Germany & Greece & 103.92 & 69.00 & 34.93 & 20282 & 4954 & $\mathrm{HH}$ \\
\hline Germany & Sweden & 63.63 & 74.59 & $(10.96)$ & 20282 & 16304 & $\mathrm{HH}$ \\
\hline Germany & Russia & 40.80 & 27.79 & 13.02 & 20282 & 2407 & $\mathrm{HL}$ \\
\hline Germany & Portugal & 49.37 & 25.43 & 23.94 & 20282 & 5087 & $\mathrm{HH}$ \\
\hline Germany & Hungary & 51.53 & 49.42 & 2.10 & 20282 & 2273 & HL \\
\hline Greece & $\mathrm{UK}$ & 47.33 & 48.28 & $(0.95)$ & 4954 & 12879 & $\mathrm{HH}$ \\
\hline Greece & Italy & 31.32 & 27.89 & 3.43 & 4954 & 14944 & $\mathrm{HH}$ \\
\hline Hong Kong & Chinese-Taipei & 76.59 & 67.11 & 9.48 & 11199 & 9225 & $\mathrm{HH}$ \\
\hline Hong Kong & Japan & 55.37 & 49.73 & 5.65 & 11199 & 23935 & $\mathrm{HH}$ \\
\hline Hong Kong & UK & 55.36 & 44.78 & 10.58 & 11199 & 12879 & $\mathrm{HH}$ \\
\hline Hong Kong & Australia & 40.27 & 32.86 & 7.41 & 11199 & 13690 & $\mathrm{HH}$ \\
\hline Hong Kong & Singapore & 41.92 & 43.80 & $(1.88)$ & 11199 & 11748 & $\mathrm{HH}$ \\
\hline India & Saudi Arabia & 49.14 & 29.49 & 19.65 & 394 & 13690 & $\mathrm{LH}$ \\
\hline Indonesia & Singapore & 36.22 & 42.20 & $(5.98)$ & 643 & 11748 & LH \\
\hline Italy & Spain & 57.54 & 59.55 & $(2.01)$ & 14944 & 8876 & $\mathrm{HH}$ \\
\hline Italy & Austria & 41.62 & 39.99 & 1.63 & 14944 & 17645 & $\mathrm{HH}$ \\
\hline Italy & Netherlands & 35.06 & 39.78 & $(4.72)$ & 14944 & 16856 & $\mathrm{HH}$ \\
\hline Japan & South Korea & 144.46 & 93.69 & 50.76 & 23935 & 4981 & $\mathrm{HH}$ \\
\hline Japan & Thailand & 61.92 & 26.46 & 35.46 & 23935 & 1601 & $\mathrm{HL}$ \\
\hline Netherlands & Germany & 287.31 & 284.31 & 3.00 & 16856 & 20282 & $\mathrm{HH}$ \\
\hline Netherlands & Belgium & 205.49 & 200.61 & 4.88 & 16856 & 16125 & $\mathrm{HH}$ \\
\hline Netherlands & UK & 156.68 & 136.42 & 20.26 & 16856 & 12879 & $\mathrm{HH}$ \\
\hline Norway & Sweden & 99.02 & 104.37 & $(5.35)$ & 23771 & 19233 & $\mathrm{HH}$ \\
\hline Norway & UK & 50.13 & 41.18 & 8.95 & 23771 & 12879 & $\mathrm{HH}$ \\
\hline Portugal & Spain & 35.66 & 34.44 & 1.22 & 5087 & 8876 & $\mathrm{HH}$ \\
\hline Singapore & Malaysia & 147.80 & 119.55 & 28.25 & 11748 & 2751 & HL \\
\hline Spain & US & 59.89 & 108.30 & $(48.41)$ & 8876 & 19940 & $\mathrm{HH}$ \\
\hline Sweden & Finland & 106.80 & 94.60 & 12.20 & 19233 & 17735 & $\mathrm{HH}$ \\
\hline Sweden & UK & 64.80 & 54.18 & 10.62 & 19233 & 12879 & $\mathrm{HH}$ \\
\hline Sweden & US & 55.94 & 65.12 & $(9.18)$ & 19233 & 19940 & $\mathrm{HH}$ \\
\hline Switzerland & Germany & 368.25 & 339.91 & 28.34 & 26914 & 20282 & $\mathrm{HH}$ \\
\hline Switzerland & France & 261.75 & 144.34 & 117.41 & 26914 & 17663 & $\mathrm{HH}$ \\
\hline
\end{tabular}

Income

GDP per capita ${ }^{a}$

17663

1553

$2407 \quad \mathrm{HL}$

2273 HL

$12879 \quad \mathrm{HH}$

$9225 \quad \mathrm{HH}$

$23935 \quad \mathrm{HH}$

$13690-\mathrm{HH}$

$11748 \quad \mathrm{HH}$

$13690 \quad$ LH

$17645 \quad \mathrm{HH}$

$16856 \quad \mathrm{HH}$

$20282 \quad \mathrm{HH}$

$12879 \quad \mathrm{HH}$

$19233 \quad \mathrm{HH}$

$12879 \quad \mathrm{HH}$

$19940 \quad \mathrm{HH}$

$17735-\mathrm{HH}$

$20282 \quad \mathrm{HH}$ 
IMTS traffic million minutes

Bilateral market

\begin{tabular}{|c|c|c|c|c|c|c|c|}
\hline \multicolumn{2}{|l|}{ Bliateral marke } & \multirow[b]{2}{*}{ (1) } & \multirow[b]{2}{*}{ (2) } & \multirow{2}{*}{$\begin{array}{l}\text { Deficit } \\
\text { (surplus) }\end{array}$} & \multicolumn{3}{|c|}{ UDF per capila } \\
\hline Country (1) & Country (2) & & & & (1) & (2) & High/Low ${ }^{\text {b }}$ \\
\hline Switzerland & Italy & 231.14 & 156.12 & 75.03 & 26914 & 14944 & $\mathrm{HH}$ \\
\hline Switzerland & UK & 88.44 & 86.88 & 1.56 & 26914 & 12879 & $\mathrm{HH}$ \\
\hline Switzerland & US & 70.12 & 105.84 & $(35.72)$ & 26914 & 19940 & $\mathrm{HH}$ \\
\hline Chinese-Taipei & Japan & 58.62 & 81.76 & $(23.14)$ & 9225 & 23935 & $\mathrm{HH}$ \\
\hline UAE & India & 67.58 & 28.89 & 38.69 & 14944 & 394 & HL \\
\hline UK & France & 290.36 & 287.84 & 2.52 & 12879 & 17663 & $\mathrm{HH}$ \\
\hline UK & Ireland & 288.10 & 215.69 & 72.41 & 12879 & 11773 & $\mathrm{HH}$ \\
\hline UK & Italy & 140.60 & 127.39 & 13.21 & 12879 & 14944 & $\mathrm{HH}$ \\
\hline UK & Spain & 128.44 & 127.55 & 0.89 & 12879 & 8876 & $\mathrm{HH}$ \\
\hline US & Canada & 2499.23 & 1691.40 & 807.83 & 19940 & 15660 & $\mathrm{HH}$ \\
\hline US & Mexico & 1458.53 & 661.90 & 796.63 & 19940 & 1845 & $\mathrm{HL}$ \\
\hline US & UK & 824.53 & 549.98 & 274.54 & 19940 & 12879 & $\mathrm{HH}$ \\
\hline US & Germany & 592.27 & 355.71 & 236.56 & 19940 & 20282 & $\mathrm{HH}$ \\
\hline US & Japan & 428.80 & 289.38 & 139.42 & 19940 & 23935 & $\mathrm{HH}$ \\
\hline US & France & 275.18 & 153.94 & 121.24 & 19940 & 17663 & $\mathrm{HH}$ \\
\hline US & Philippines & 233.57 & 54.77 & 178.80 & 19940 & 612 & $\mathrm{HL}$ \\
\hline US & Italy & 229.22 & 136.38 & 92.84 & 19940 & 14944 & $\mathrm{HH}$ \\
\hline US & Chinese-Taipei & 194.42 & 92.25 & 102.17 & 19940 & 9225 & $\mathrm{HH}$ \\
\hline US & Brazil & 187.82 & 63.63 & 124.19 & 19940 & 1963 & HL \\
\hline US & Hong Kong & 176.08 & 89.04 & 87.04 & 19940 & 11199 & $\mathrm{HH}$ \\
\hline US & Israel & 168.10 & 54.69 & 113.41 & 19940 & 9775 & $\mathrm{HH}$ \\
\hline US & India & 156.44 & 53.44 & 102.99 & 19940 & 394 & $\mathrm{HL}$ \\
\hline US & Australia & 139.27 & 120.78 & 18.49 & 19940 & 13690 & $\mathrm{HH}$ \\
\hline US & Netherlands & 114.27 & 76.37 & 37.90 & 19940 & 16856 & $\mathrm{HH}$ \\
\hline Venezuela & US & 52.25 & 87.20 & $(34.95)$ & 2735 & 19940 & $\mathrm{LH}$ \\
\hline
\end{tabular}

Note: ${ }^{\mathrm{a}}$ denotes average real GDP per capita (US\$) 1991-95; ${ }^{\mathrm{b}} \mathrm{H}$ denotes high income country, L denotes low income country. Source. CEPD (1997), ITU (1996), TeleGeography Inc. (1997), World Bank (1997).
Income

Income
DP per capita 